\title{
Sleep, quality of life and mood of nursing professionals of Pediatric Intensive Care Units
}

\author{
Sono, qualidade de vida e humor em profissionais de enfermagem \\ em Unidades de Terapia Intensiva Infantil \\ Sueño, calidad de vida y humor en profesionales de enfermería \\ en Unidades de Cuidados Intensivos Infantiles
}

Priscilla Caetano Guerra ${ }^{1}$, Nilton Ferraro Oliveira ${ }^{1}$, Maria Teresa de Sande e Lemos Ramos Ascensão Terreri², Claudio Arnaldo Len²

How to cite this article:

Guerra PC, Oliveira NF, Terreri MTRA, Len CA. Sleep, quality of life and mood of nursing professionals of pediatric intensive care units. Rev Esc Enferm USP. 2016;50(2):277-283. DOI: http://dx.doi.org/10.1590/S0080-623420160000200015

${ }^{1}$ Universidade Federal de São Paulo, Escola Paulista de Medicina, Departamento de Pediatria, São Paulo, SP, Brazil.

${ }^{2}$ Universidade Federal de São Paulo, Escola Paulista de Medicina, Professor Adjunto, Departamento de Pediatria, Setor de Reumatologia, São Paulo, SP, Brazil.

\section{ABSTRACT}

Objective: To assess sleep, quality of life and mood of nursing professionals of pediatric intensive care units. Method: Quantitative, cross-sectional and descriptive study. Professionals grouped by morning, afternoon and evening shifts were assessed by means of the instruments: Morningness-Eveningness Questionnaire; Pittsburgh Sleep Quality Index; Epworth Sleepiness Scale; Generic questionnaire for the assessment of quality of life (SF-36); Beck Depression Inventory; Beck Anxiety Inventory; State-Trait Anxiety Inventory. Results: Sample consisted of 168 professionals, with prevalence of neutral typology (57.49\%). There was no statistical significance regarding sleep, despite scores showing a poor quality of sleep and excessive daytime sleepiness for the three shifts. Quality of life did not reveal any statistical significance, but in the field "social role functioning" of the evening shift, a lower score was observed $(p<0.007)$. There was no statistical significance regarding levels of anxiety and depression. Conclusion: The results suggest that these professionals may present sleeping problems, but they do not have lower scores of quality of life or mood disorders. Likely explanations for these findings may include an adaptation to their work type over time and the fact that working with children is rewarding.

\section{DESCRIPTORS}

Sleep; Quality of Life; Mood Disorders; Nursing Team; Shifts Work; Intensive Care Units, Pediatric. 


\section{INTRODUCTION}

Nursing professionals of pediatric and neonatal intensive care units are subject to an intense and stressful workload, since they deal with the lives of patients at risk and are required to make decisions that are often complex. In addition to this, they work in shifts, on holidays and weekends, which differentiates them from other workers with regard to their work regime ${ }^{(1)}$.

Studies have shown that this type of activity has an impact on sleep, quality of life and $\operatorname{mood}^{(2-4)}$. Therefore, the measurement of these aspects is important so that we can better understand nurses' routine and the effects on multiprofessional teams.

Complaints related to sleep are common among those who work on duty. Working in shifts favors the increase of daytime sleepiness and the decrease in the state of readiness of individuals, offering a greater risk of injuries and work accidents ${ }^{(2)}$. These findings were observed in a study ${ }^{(5)}$ which assessed the quality of sleep of nurses who work in intensive care units, by means of the Pittsburgh Sleep Quality Index (PSQI). The authors showed that the quality of sleep of nursing professionals is poor, and this may compromise their work performance.

Despite the subjectivity of the concept of quality of life, we made use of objective questionnaires for measurement, the generic questionnaire SHORT FORM 36 - SF-36. The Medical Outcomes Study 36 - Item Short Form Health Survey ${ }^{(6)}$ includes eight sections or aspects: vitality, physical functioning, bodily pain, general health perceptions, physical role functioning, emotional role functioning, social role functioning, and mental health. Working in shifts and with critical patients may have an impact on different aspects of the quality of life of nursing professionals ${ }^{(3)}$. On the other hand, there is a limited number of studies on the topic, in addition to the fact that we can observe important differences in working environments and in patients' characteristics ${ }^{(7)}$. We assume that the quality of life of professionals who work in pediatric and neonatal intensive care units may be undermined.

Just as important as the assessment of sleep and quality of life, the identification of mood disorders is necessary, as well as of the outbreak of anxiety, depression, irritability, angst, tension, confusion, fatigue, psychological and emotional changes, difficulties of interacting, mood swings and deterioration of family relationships ${ }^{(4)}$. It is supposed that the fact of taking care of children and teenagers may be associated with mood disorders within the health care staff, since these patients have technical particularities, such as difficult venous access or pressure made by relatives. However, we have not found nursing studies aimed at measuring mood disorders in pediatric and neonatal intensive care units.

After carrying out an extensive review of this topic, we observed that the number of publications involving nursing professionals who work at pediatric and neonatal intensive care units is scarce ${ }^{(7)}$. To our knowledge, this is the first study based on questionnaires for the assessment of sleep, quality of life and mood disorder of these pediatric and neonatal intensive care unit professionals. All questionnaires were translated into Portuguese and validated, and they are self-administered and easy to interpret; moreover, they are clinically useful for the assessment of the respective disorders that are measured. Thus, we were encouraged to assess, by means of standardized instruments, the three aspects in question among one single population: 1 ) Quality of sleep; 2) Quality of life and 3) Presence of mood disorders in nursing professionals divided into work shifts (morning, afternoon and evening).

\section{METHOD}

This is a quantitative, cross-sectional and descriptive study. A primary data collection was carried out by means of questionnaires applied to the subjects.

The survey was conducted between November 2012 and April 2014 in pediatric and neonatal intensive care units of five teaching hospitals of a metropolitan area.

The nursing professionals $(n=168)$ who participated in this study were divided into shifts: morning (69), afternoon (29) and evening (70), and these shifts had either six, eight or twelve hours in a 36-hour week, according to their employment contract.

The selection was consecutive and all professionals who were present in the shifts were invited to participate.

Data collection was carried out by one of the researchers (P.C.G.), who monitored and provided guidance regarding the completion of self-reported questionnaires during duty breaks or entry and exit of professionals, when she also cleared possible doubts.

With the purpose of obtaining greater participation of subjects while nurses were performing duties that could not be interrupted, questionnaires were handed over and a deadline of seven days was established to return them.

The study began after the project was approved by the local ethics committee, under number 110.472. All participants signed a free and informed consent form.

Protocol for Demographic Data Collection: produced by the research team for this study. It included questions about sociodemographic details of nursing professionals.

Pittsburgh Sleep Quality Index (PSQI): measurement of quality of sleep. This questionnaire consists of 19 selfadministered questions, divided into seven components: subjective quality of sleep, sleep onset latency, sleep duration, normal sleep effectiveness, sleep disorders, use of sleeping pills and daytime dysfunction. The global score ranges between 0 to 21 and the higher the score, the poorer the quality of sleep. A global PSQI score of $>5$ indicates that the individual is having great difficulties in at least two components, or moderate difficulties in more than three components ${ }^{(8-9)}$, suggesting that quality of sleep is either good or poor.

Epworth sleepiness scale (ESS): self-administered questionnaire that refers to the possibility of dozing off 
in eight daily situations. It consists of a scale from 0 to 3 , in which 0 corresponds to none and 3 to a great probability of dozing off ${ }^{(10-11)}$. ESS $\leq 10$ corresponds to the absence of sleepiness; ESS = 11-15 suggests excessive daytime sleepiness; ESS $\geq 16$ indicates severe sleepiness.

Morningness-Eveningness Questionnaire (MEQ): questionnaire for the identification of individuals as to their morningness-eveningness. The questionnaire result corresponds to a final score that may vary between 86 and 16 points. Scores between 86 and 70 represent morning individuals; between 69 and 59, rather morning individuals; between 58 and 42, neutral individuals; between 41 and 31, rather evening individuals; between 30 and 16 , afternoon individuals ${ }^{(12-13)}$.

Generic questionnaire for the assessment of quality of life $(S F-36)$ : measures quality of life. It is a multidimensional questionnaire composed of 36 items, including eight sections or aspects: vitality, physical functioning, bodily pain, general health perceptions, physical role functioning, emotional role functioning, social role functioning, and mental health. It has a final score of 0 to 100 , in which zero corresponds to the worst general state of health and 100 to the best state of health ${ }^{(6,14)}$.

Beck Depression Inventory (BDI): this inventory distinguishes normal from depressed or anxious individuals, and is a self-applied scale. This instrument is composed of 21 categories of symptoms and behaviors that describe conduct, cognitive, emotional and somatic manifestations of depression. The score for each item varies from zero to three, where zero corresponds to the absence of depressive symptoms and three indicates the presence of more intense symptoms. BDI $<9-$ absence of depression or minimal depressive symptoms, $10-18$ - slight to moderate depression, 19-29 - moderate to severe depression, 30-63 - severe depression ${ }^{(15-16)}$.

Beck Anxiety Inventory (BAI): assesses the intensity of anxiety symptoms in depressed patients. It consists of 21 items which reflect somatically, emotionally and cognitively the typical anxiety symptoms, but not those related to depression. This is a four-point scale which varies from zero (no to all) to three (severely). The added items result in a total score that may vary from zero to 63 . BAI $<10-$ absence of anxiety or minimal anxiety symptoms, 11-19 - slight to moderate anxiety, 20-30 - moderate to severe anxiety, 31-63 - severe anxiety ${ }^{(17)}$.

State-Trait Anxiety Inventory (STAI): self-reported questionnaire used to monitor states of anxiety, which is composed of two different scales created to measure two concepts of anxiety, that is, an anxious state (AI-State) and an anxious trait (AI-Trait). Each scale consists of 20 statements with scores that vary between 1 and 4 . The total score of each scale varies between 20 and 80 points, where higher values indicate higher levels of anxiety ${ }^{(16,18)}$.

A descriptive analysis was performed to assess the values of results collected and the sample profile, according to the variables being studied. Frequency tables were produced for category variables (with figures of absolute (N) and percentage (\%) frequency).

The non-parametric Kruskal-Wallis test was used to compare the numeric variables. The significance level adopted for the statistical tests was $5 \%$, that is, a $\mathrm{p}$ value equal to or lower than 0.05 for a statistically significant result $(\mathrm{p}<0.05)$. Results that were not significant were not discussed in this study.

Data collected were entered in Excel for Windows 7 (Microsoft Office 2007) and, subsequently transferred to SPSS - System for Windows (Statistical Analysis System), version 19 (SAS Institute Inc., 2002-2003, Cary, NC, USA). All the statistical processing support was provided by professionals from the Statistical Office of the Foundation for Research Support.

\section{RESULTS}

Regarding sociodemographic data and characteristics of the professional activity of the 168 individuals participating in the study, it was found that $79.17 \%$ of them had been working in a pediatric ICU and $20.83 \%$ in a neonatal ICU. It was observed that $41.07 \%$ worked during morning shifts, $17.26 \%$ in afternoon shifts and $41.67 \%$ in evening shifts. There was a balance between each other's duties, and the sample was made up of $29.26 \%$ of nurses, $33.54 \%$ of nursing aides and $37.20 \%$ of nursing technicians, where $67.86 \%$ of these professionals had performed their functions for at least 10 years, and $32.14 \%$ for 11 to 30 years. Individuals were predominantly women (94.05\%), up to 40 years old (74.31\%), and were in a stable relationship (58.18\%).With regard to the household budget, $60.12 \%$ of individuals were responsible for providing up to $50 \%$ of it. As for education, $41.67 \%$ completed secondary school, $26.79 \%$ were studying or had completed an undergraduate course, and $31.54 \%$ were studying or had completed a graduate course.

To assess daytime sleepiness, the ESS was applied. A prevalence of severe sleepiness for evening shifts, and excessive daytime sleepiness for morning shifts were observed. Results obtained are presented in Table 1.

Table 1 - Scores of the Epworth Sleepiness Scale (ESS) for different shifts - São Paulo, SP, Brazil, 2012 to 2014.

\begin{tabular}{lcccccc}
\hline & \multicolumn{2}{c}{ Morning } & \multicolumn{2}{c}{ Afternoon } & \multicolumn{3}{c}{ Evening } \\
\cline { 2 - 6 } & $\mathbf{n}$ & $\mathbf{( \% )}$ & $\mathbf{n}$ & $\mathbf{( \% )}$ & $\mathbf{n}$ & $\mathbf{( \% )}$ \\
\hline Lack of sleepiness $\leq 10$ & 29 & $(37.18)$ & 16 & $(20.51)$ & 33 & $(42.31)$ \\
Excessive daytime sleepiness $11-15$ & 30 & $(46.87)$ & 11 & $(17.19)$ & 23 & $(35.94)$ \\
Severe sleepiness $\geq 16$ & 8 & $(36.36)$ & 1 & $(4.55)$ & 13 & $(59.09)$ \\
\hline
\end{tabular}

Note: $(n=164)$. 
Considering the quality of sleep and the prevalence of the chronotype of professionals who participated in the study, a predominance of neutral individuals was observed, as shown in Table 2 .

Table 2 - Frequency distribution of individuals according to scores in the Pittsburgh Sleep Quality Index (PSQI) and the MorningnessEveningness Questionnaire (MEQ), by work shifts - São Paulo, SP, Brazil, 2012 to 2014.

\begin{tabular}{|c|c|c|c|c|c|c|}
\hline \multirow{3}{*}{ Chronotype } & \multicolumn{2}{|c|}{ Morning } & \multicolumn{2}{|c|}{ Afternoon } & \multicolumn{2}{|c|}{ Evening } \\
\hline & \multicolumn{6}{|c|}{ Quality of Sleep } \\
\hline & Good & Poor & Good & Poor & Good & Poor \\
\hline Total & 29 & 39 & 17 & 12 & 24 & 39 \\
\hline Morning & 3 & 2 & 0 & 0 & 0 & 0 \\
\hline Rather morning & 9 & 10 & 4 & 2 & 4 & 3 \\
\hline Afternoon & 1 & 1 & 1 & 1 & 0 & 2 \\
\hline Rather afternoon & 1 & 6 & 5 & 4 & 3 & 5 \\
\hline Neutral & 15 & 20 & 7 & 5 & 17 & 29 \\
\hline
\end{tabular}

Note: $(n=167)$.

Regarding the quality of life profile (Table 3), most fields of the SF-36 test did not have statistical significance for the three different groups, the only exception being social role functioning $(\mathrm{p}=0.007)$. Evening shifts had a lower score when compared to morning shifts $(\mathrm{p}=0.022)$ and afternoon shifts $(\mathrm{p}=0.004)$. By contrast, morning and afternoon shifts had the same score profile $(\mathrm{p}=0.244)$, as shown in Table 4.

Table 3 - Average ranks of SF-36 quality of life scores per shift - São Paulo, SP, Brazil, 2012 to 2014.

\begin{tabular}{lcccc}
\hline Field & Morning & Afternoon & Evening & p value \\
\hline Physical functioning & 84.45 & 97.60 & 77.93 & 0.179 \\
Physical limitation & 83.40 & 92.21 & 81.19 & 0.552 \\
Pain & 83.09 & 86.78 & 83.74 & 0.940 \\
General health perceptions & 82.76 & 95.72 & 80.34 & 0.340 \\
Vitality & 89.76 & 84.74 & 75.50 & 0.210 \\
Social role functioning & 88.42 & 100.34 & 70.18 & $0.007^{*}$ \\
Emotional role functioning & 82.49 & 95.88 & 80.55 & 0.236 \\
Mental health & 79.46 & 88.28 & 84.29 & 0.677 \\
Total score & 102.21 & 72.59 & 71.04 & 0.121 \\
\hline
\end{tabular}

Note: ( $\mathrm{n}=168)$. Kruskal-Wallis non-parametric test, statistical significance $(\mathrm{p}<0.05)$.

*Significant correlations are underlined in the table.

Table 4 - Multiple comparison for the social role functioning between different shifts - São Paulo, SP, Brazil, 2012 to 2014.

\begin{tabular}{lc}
\hline Multiple comparisons & p value \\
\hline Morning and afternoon & 0.244 \\
Morning and evening & 0.022 \\
Afternoon and evening & 0.004 \\
\hline
\end{tabular}

Nota: (n=168). Kruskal-Wallis non-parametric test.

Concerning mood analysis, the BAI, BDI and STAI tests were used by works shifts, and there was no statistical significance for scores of these instruments. Most individuals had no depression or anxiety in BDI and BAI, respectively. Likewise, the sample profile, according to STAI had slight or no indication of anxiety.

\section{DISCUSSION}

We have found in our study a poor quality of sleep among nursing professionals of pediatric intensive care units, regardless of their work shifts. The main strength of our methodology was the systematic use of questionnaires validated internationally. Even though professionals work in three different shifts (morning, afternoon and evening), they are all under stress during their work routine, since they deal with patients in critical conditions. 
QUALITY OF LIFE AND MOOD DISORDER IN NURSING PROFESSIONALS OF PEDIATRIC AND NEONATAL ICUS

Although we studied professionals from units that were different regarding patients' age group, namely neonatal and pediatric, and also regarding work shifts, the work routine is similar since they all have direct contact with patients in critical conditions and their relatives ${ }^{(19)}$. Most professionals (67.86\%) had been performing their duties for less than 10 years on average, and only $5.35 \%$ had done it for more than 20 years; also, $74.31 \%$ were less than 40 years old.

These figures have been reported in other studies which involved professionals who worked in similar units ${ }^{(20)}$, and they show that, despite having a specific professional training and $31.54 \%$ are studying or have completed graduate programs, these professionals do not remain in this activity for long. These results suggest that more experienced professionals change their activity over the years, probably to less stressful and less emotionally consuming ones.

Our initial hypotheses were that scores of quality of life (SF-36) were generally low, and scores of mood disorder questionnaires (BAI, BDI and STAI) indicated higher levels of anxiety and depression. Nevertheless, such results were not found, that is, the only finding statistically observed concerned the social role functioning in SF-36; our data shows that, despite the scores of global quality of life being within the average, evening shift professionals had lower scores in social role functioning when compared to the other groups. These data may be related to the lack of time for social and leisure activities found among these professionals.

Another study ${ }^{(21)}$ had the objective to analyze the relationship between quality of sleep and quality of life of 264 nursing professionals who worked in shifts and it showed a close relationship between these variables, indicating a decrease in the quality of sleep associated with shift, age and gender, thus compromising the professionals' quality of life.

Another study ${ }^{(3)}$, which assessed the relationship between stress related to work, burnout, professional satisfaction and general state of health in 1,200 nurses of four hospitals, showed that burnout had a significant impact on the nurses' mental health deterioration, which affected their productivity, performance and also quality of care.

In a multi-center study ${ }^{(4)}$ carried out in 31 intensive care units, which aimed to assess whether the prevalence of burnout, depression and safety rules affected medical errors or adverse effects, it was observed that the frequency of iatrogenesis in these units was high when the team had symptoms of depression.

To confirm these findings, another study ${ }^{(22)}$ which analyzed the nursing practice taking into account health, number of hours worked, professional satisfaction, adequate sleep, condition of naps during duties and the balance between family and professional relationships, suggested that different utilizations be used in order to have a sound environment for professional practices with the aim to improve nurses' health.

In addition, a literature review study ${ }^{(23)}$ tried to find whether there was a relationship between personality and the specialty chosen by nursing professionals, and it suggested that there is evidence of a relationship between personality features, the specialty chosen, burnout and professional satisfaction. Bibliographic references about this topic were found to be limited and the effect of personality on the will to remain in the activity was not closely related.

To our knowledge, this is the first study based on questionnaires for the assessment of sleep disorders, quality of life and mood disorders of professionals of pediatric and neonatal intensive care units.

Possible explanations for adequate quality of life scores are: 1) professionals' adaptation to work shifts, which includes rest periods that are sufficient to recover a sound routine; 2) typology of individuals, since they try to work according to their characteristics. According to the MEQ (Table 2), a certain prevalence of professionals with the typology 'morning' and/or 'rather morning' for morning shifts was observed; and professionals with the typology 'afternoon' and/or 'rather afternoon' were equally distributed over the three shifts; and those with neutral typology $(57.49 \%)$ prevailed in the evening shift; these individuals are capable of working in random hours without any negative effects on their bodies ${ }^{(20)}$; 3) working with children is rewarding. A study ${ }^{(7)}$ carried out in two pediatric oncology centers with a sample of 107 health professionals, including nurses, concluded that despite the work being stressful and complex, working with children can be rewarding and provide welfare within the team and a decrease in stress.

\section{QUALITY OF SLEEP OF NURSING PROFESSIONALS OF PEDIATRIC AND NEONATAL ICUS}

It is considered that the schedule may bring important difficulties to family and social life plans, as a result of the lack of family and social contact, which in turn results from weariness related to work in shifts. Manifestations of depression or unhappiness can be observed, as well as irritability, feelings of low self-esteem and mood instability of workers ${ }^{(4)}$.

In our study, after the application of the PSQI and ESS questionnaires for the assessment of sleep, we did not observe significant differences between quality of sleep and excessive daytime sleepiness in the three groups. However, in the qualitative assessment, there was a frequency of poor quality of sleep among the individuals in the three shifts for the PSQI test and the ESS total score indicated an excessive daytime sleepiness among individuals from the three shifts as well.

The aim of another study ${ }^{(2)}$ was to describe the acute and chronic effects of the lack of sleep within the nursing team. It mentioned the little attention given to this topic and suggested the creation of a policy that promotes better quantity and quality of sleep for these professionals.

Another study ${ }^{(20)}$ which aimed to analyze the sleep-wake cycle and the quality of sleep of 60 nurses who work in shifts showed: poor quality of sleep; indifferent prevalence of chronotype; period of awakening and falling asleep during days of the week and weekends statistically different, suggesting that these professionals do not have enough rest during the week. 
A study ${ }^{(24)}$, which attempted to find symptoms related to the general state of health associated with work in shifts and relate them to the quality of sleep of 136 nursing professionals, observed the occurrence of changes in physical and mental health, regardless of the shift, and a worse quality of night sleep of professionals who worked in morning shifts.

\section{STUDY WEAKNESSES AND LIMITATIONS}

Some difficulties encountered during data collection may have interfered with the results: the possibility of professionals with serious problems, especially psychological ones, being on sick leave; not including professionals from public hospitals, places in which structural problems (food, comfort, pay) are more common; unwillingness of professionals to respond to questionnaires when they realized that the questions were about their affective life; some professionals refused to fill in when they noticed that it was composed of eight multiple choice questions, and the average time for completion was 15 minutes, and so it was for incomplete ones, which resulted in the loss of data. In addition to this, there was a difficulty in finding a place to complete them and also to agree upon a time to do it. Another limitation concerns the use of the SF-36 instrument, which has been frequently applied to measure results of medical care, being limited to show aspects of quality of life.

In this sense, results of this study suggest that the frequency of poor social role functioning obtained in the SF36, excessive daytime sleepiness and poor quality of sleep can be observed among professionals. Thus, the great challenge of night workers is definitely to adapt their pace of life to their biological clock and to social coexistence ${ }^{(25)}$.

\section{CONCLUSION}

The results suggest that these professionals may present sleeping problems, but they do not have lower scores of quality of life or mood disorders. Likely explanations for these findings may include an adaptation to their work type over time and the fact that working with children is rewarding.

\section{RESUMO}

Objetivo: Avaliar sono, qualidade de vida e humor em profissionais de enfermagem em Unidades de Terapia Intensiva Infantil. Método: Estudo quantitativo, transversal e descritivo. Profissionais agrupados por turnos matutino, vespertino e noturno foram avaliados pelos instrumentos: Questionário de identificação Matutinidade-Vespertinidade; Índice de qualidade do sono de Pittsburgh; Escala de sonolência Epworth; Questionário genérico de avaliação de qualidade de vida - SF-36; Inventário de depressão de Beck; Inventário de ansiedade de Beck; Inventário de ansiedade Traço-Estado. Resultados: Amostra composta por 168 profissionais, predominando tipologia neutra, 57,49\%. Não houve significância estatística quanto ao sono, apesar dos escores mostrarem qualidade ruim e sonolência diurna excessiva para os três turnos. A qualidade de vida não denotou diferença estatística, mas no domínio "aspecto social" do turno noturno, observou-se escore pior $(p<0,007)$. Não houve significância estatística nos níveis de ansiedade e depressão. Conclusão: Os resultados sugerem que estes profissionais podem apresentar problemas no sono, entretanto não apresentam escores mais baixos de qualidade de vida ou transtornos do humor. Possíveis explicações para estes achados são que haja uma adaptação ao regime de trabalho ao longo do tempo e que trabalhar com crianças seja recompensador.

\section{DESCRITORES}

Sono; Qualidade de Vida; Transtornos do Humor; Equipe de Enfermagem; Trabalho em Turnos; Unidades de Terapia Intensiva Pediátrica.

\section{RESUMEN}

Objetivo: Evaluar el sueño, la calidad de vida y el humor en profesionales de enfermería en Unidades de Cuidados Intensivos Infantiles. Método: Estudio cuantitativo, transversal y descriptivo. Profesionales agrupados por turno matutino, vespertino y nocturno fueron evaluados por los instrumentos: Cuestionario de identificación Matutinidad-Vespertinidad; Índice de calidad del sueño de Pittsburgh; Escala de somnolencia de Epworth; Cuestionario genérico de evaluación de calidad de vida - SF-36; Inventario de depresión de Beck; Inventario de ansiedad de Beck; Inventario de ansiedad Trazo-Estado. Resultados: Muestra compuesta de 168 profesionales, predominando la tipología neutra en el 57,49\%. No hubo significación estadística en cuanto al sueño, pese a que los puntajes muestren mala calidad y somnolencia diurna excesiva para los tres turnos. La calidad de vida no denotó diferencia estadística, pero en el dominio “aspecto social" del turno nocturno, se observó puntaje peor $(\mathrm{p}<0,007)$. No hubo significación estadística en los niveles de ansiedad y depresión. Conclusión: Los resultados sugieren que esos profesionales pueden presentar problemas en el sueño, sin embargo no presentan puntajes más bajos de calidad de vida o trastornos del humor. Posibles explicaciones para dichos hallazgos son que exista una adaptación al régimen laboral a lo largo del tiempo y que trabajar con niños sea recompensador.

\section{DESCRIPTORES}

Sueño; Calidad de Vida; Trastornos del Humor; Grupo de Enfermería; Trabajo por Turnos; Unidades de Cuidado Intensivo Pediátrico.

\section{REFERENCES}

1. Brasil. Ministério da Saúde; Agência Nacional de Vigilância Sanitária. Resolução n. 7, de 24 de fevereiro de 2010. Dispõe sobre os requisitos mínimos para funcionamento de Unidades de Terapia Intensiva e dá outras providências [Internet]. Brasília; 2010 [citado 2013 nov. 10]. Disponível em: http://bvsms.saude.gov.br/bvs/saudelegis/anvisa/2010/res0007_24_02_2010.html

2. Eanes L. CE: the potential effects of sleep loss on a nurse's health. Am J Nurs. 2015;115(4):34-40. 
3. Khamisa N, Oldenburg B, Peltzer K, Ilic D. Work related stress, burnout, job satisfaction and general health of nurses. Int J Environ Res Public Health. 2015;12(1):652-66.

4. Garrouste-Orgeas M, Perrin M, Soufir L, Vesin A, Blot F, Maxime V, et al. The iatroref study: medical errors are associated with symptoms of depression in ICU staff but not burnout or safety culture. Intensive Care Med. 2015;41(2):273-84.

5. Santos TCM, De Faria AL, Feitosa MS, Coimbra GT, Ferreira LC, De Martino MMF. Quality and sleep disturbances of the nursing staff of a therapy unit. Rev. Enferm UFPE Online [Internet]. 2014 [cited 2014 nov. 15];8(5):1110-6. Available from: http://www.revista.ufpe.br/ revistaenfermagem/index.php/revista/article/view/5292/pdf_4993

6. Ware JE, Snow KK, Kosinski M, Gandek B. SF-36 - Health Survey: manual and interpretation guide. Boston: Health Institute; 1993.

7. Bowden MJ, Mukherjee S, Williams LK, DeGraves S, Jackson M, McCarthy MC. Work-related stress and reward: an Australian study of multidisciplinary pediatric oncology healthcare providers. Psychooncology. 2015;24(11):1432-8.

8. Buysse DJ, Reynolds CF, Monk TH, Berman SR, Kupfer DJ. The Pittsburgh Sleep Quality Index: a new instrument for psychiatric practice and research. Psychiatr. Res.1989;28(2):193-213.

9. Bertolazi AN, Fagondes SC, Hoff LS, Dartora EG, Miozzo IC, Barba ME, et al. Validation of the Brazilian Portuguese version of Pittsburgh Sleep Quality Index. Sleep Med. 2011;12(1):70-5.

10. Johns MW. A new mothod for measuring daytime sleepiness: the Epworth Sleepiness Scale. Sleep. 1991;14(6):540-5.

11. Bertolazi AN, Fagondes SC, Hoff LS, Pedro VD, Menna-Barreto SS, Johns MW. Portuguese-language version of the Epworth sleepiness scale: validation for use in Brazil. J Bras Pneumol. 2009;35(9):877-83.

12. Horne JA, Östberg O. A self-assessment questionnaire to determine morningness-eveningness. Int J Chronobiol. 1976;4(2):97-110.

13. Benedito-Silva AA, Menna-Barreto L, Marques N, Tenreiro S. A self-assessment questionnaire for the determination of morningnesseveningness types in Brazil. Prog Clin Biol Res. 1990;341B:89-98.

14. Ciconelli RM, Ferraz MB, Santos W, Meinão I, Quaresma MR. Tradução para a língua portuguesa e validação do questionário genérico de avaliação de qualidade de vida SF-36 (Brasil SF-36). Rev.Bras Reumatol. 1999;39(3):143-50.

15. Beck AT, Steer RA. Beck Scale for Depression Inventory: manual. San Antonio: Psycological; 1993.

16. Gorestein C, Andrade L. Validation of a Portuguese Version of the Beck Depression Inventory and the State-Trait Anxiety Inventory in Brazilians subjects. Braz J Med Biol Res. 1996;29(4):453-7.

17. Beck AT \& Steer RA. Beck Scale for Anxiety Inventory. Manual. San Antonio. TX: Psycological Corporation, 1993.

18. Spielberg CD, Gorsuch RL, Lushene RE. Manual for the state-trait anxiety inventory. Palo Alto: Consulting Psychologist; 1970.

19. Ferreira NN, Lucca SR. Burnout syndrome in nursing assistants of a public hospital in the state of São Paulo. Rev.Bras Epidemiol. 2015;18(1):68-79.

20. De Martino MMF, Abreu ACB, Barbosa FSB, Teixeira JEM. The relationship between shift work and sleep patterns in nurses. Ciência Saúde Coletiva. 2013;18(3):763-8.

21. Palhares VC, Corrente JE, Matsubara BB. Association between sleep quality and quality of life in nursing professionals working rotating shifts. Rev Saúde Pública; 2014;48(4):597-601.

22. Kushner J, Ruffin T. Empowering a healthy practice environment. Nurs Clin North Am. 2015;50(1):167-83.

23. Kennedy B, Curtis K, Waters D. Is there a relationship between personality and choice of nursing specialty: an integrative literature review. BMC Nurs. 2014;13(1):40.

24. Mendes SS, De Martino MMF. Shift work: overall health state related to sleep in nursing workers. Rev Esc Enferm USP. 2012;46(6):1471-6.

25. Ghalich L, Pournik O, Ghaffari M, Vingard E. Sleep quality among health care workers. Arch Iran Med. 2013;16(2):100-3. 